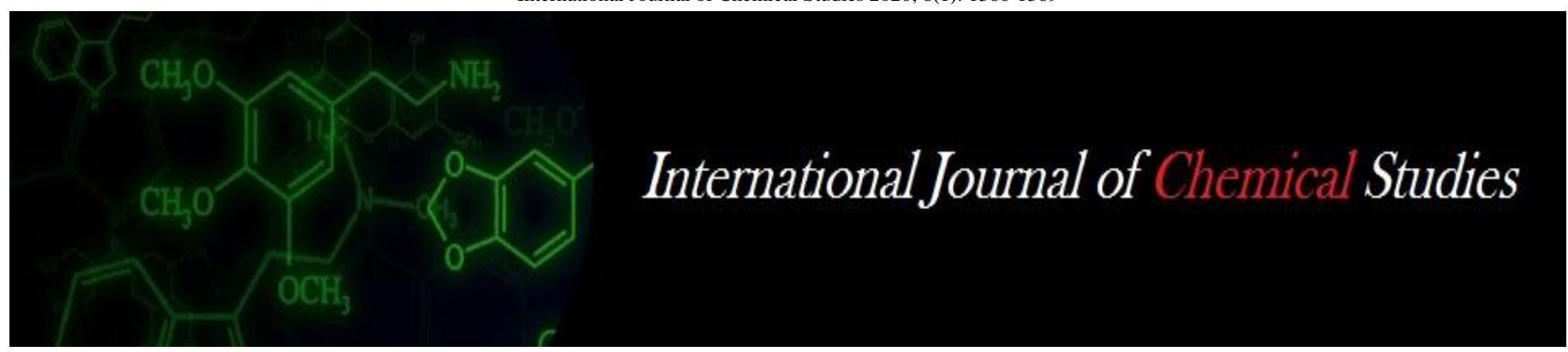

P-ISSN: 2349-8528

E-ISSN: 2321-4902

IJCS 2020; 8(1): 1366-1369

(C) 2020 IJCS

Received: 16-11-2019

Accepted: 18-12-2019

\section{P Dhal}

Department of Vegetable

Science, Odisha University of

Agriculture and Technology,

Bhubaneswar, Odisha, India

GS Sahu

Department of Vegetable Science, Odisha University of Agriculture and Technology, Bhubaneswar, Odisha, India

\section{S Mohanty}

Department of Seed Science and Technology, Odisha University of Agriculture and Technology, Bhubaneswar, Odisha, India

\section{SK Dash}

Department of Vegetable Science, Odisha University of Agriculture and Technology, Bhubaneswar, Odisha, India

\section{P Tripathy}

Department of Vegetable Science, Odisha University of Agriculture and Technology, Bhubaneswar, Odisha, India

\section{A Dhal}

Department of Plant Pathology, Odisha University of Agriculture and Technology, Bhubaneswar, Odisha, India

Corresponding Author: P Dhal

Department of Vegetable Science, Odisha University of Agriculture and Technology, Bhubaneswar, Odisha, India

\section{Effect of seed priming on growth behaviour of French bean Phaseolus vulgaris L.}

\author{
P Dhal, GS Sahu, S Mohanty, SK Dash, P Tripathy and A Dhal
}

DOI: https://doi.org/10.22271/chemi.2020.v8.i1s.8444

\begin{abstract}
An experiment entitled "Effect of seed priming on growth behaviour of French bean Phaseolus vulgaris L." was conducted during Rabi 2018-19 in the Vegetable Research field of Department of Vegetable Science, College of Agriculture, OUAT, Bhubaneswar. The trial was conducted in Randomized Block Design with three replications and ten treatments. The treatments were $\mathrm{T}_{1}$ (Hydro priming), $\mathrm{T}_{2}\left(\mathrm{GA}_{3} 50\right.$ $\mathrm{ppm}), \mathrm{T}_{3}(\mathrm{KCl} 2 \%), \mathrm{T}_{4}$ (Sodium Molybdate $500 \mathrm{ppm}$ ), $\mathrm{T}_{5}\left(\right.$ Vitavax $2 \mathrm{~g} / \mathrm{kg}$ ), $\mathrm{T}_{6}$ (Pseudomona fluorescens $10 \%), \mathrm{T}_{7}$ (Trichoderma viride $10 \%$ ), $\mathrm{T}_{8}\left(\mathrm{GA}_{3} 50 \mathrm{ppm}+T\right.$. viride $\left.10 \%\right), \mathrm{T}_{9}$ (Sodium Molybdate $500 \mathrm{ppm}$ + Pseudomonas fluorescens $10 \%$ ), $\mathrm{T}_{10}$ (Control) Good quality seeds of French bean variety Harsha was taken and different priming treatments were done in the laboratory followed by growing the crop in the field as per recommended package of practices. However days to $1^{\text {st }}$ flowering \& $50 \%$ flowering were found non-significant. Days to $50 \%$ flowering varied from 45.5 in $\mathrm{T}_{6}$ to $48.7 \mathrm{in} \mathrm{T}_{4}$. The average leaf area of the trifoliate compound leaves were taken which was highest in $\mathrm{T}_{3}(148.30)$ followed by $\mathrm{T}_{8}\left(140.40 \mathrm{~cm}^{2}\right)$ and was lowest $\left(105.8 \mathrm{~cm}^{2}\right)$ in control. The highest stem girth $(2.8 \mathrm{~cm})$ was recorded in $\mathrm{KCl}(2 \%)$ primed seeds closely followed by $\mathrm{GA}_{3}(50 \mathrm{PPM})+T$. viride $(10 \%)(2.7 \mathrm{~cm})$ and vitavax treatment @ $2 \mathrm{~g} / \mathrm{kg}(2.6$ $\mathrm{cm})$. The number of primary branches per plant was maximum in $\mathrm{T}_{3}(4.52)$ and minimum in $\mathrm{T}_{10}(2.87)$ and this character differed significantly among the treatments. The treatments $\mathrm{T}_{3}(4.52), \mathrm{T}_{8}(4.32), \mathrm{T}_{6}(4.14), \mathrm{T}_{5}$ (4.01) produced more branches and they are at par.
\end{abstract}

Keywords: Priming, leaf area, stem girth, flowering

\section{Introduction}

Seed priming is a pre sowing treatment which leads to a physiological state that enables seed to germinate more efficiently. Seed priming is a technique which involves water uptake by seeds followed by drying to initiate the early events of germination up to the point of radicle germination, improved seedling vigour and growth under a broad range of environments resulting in better stand establishment and alleviation of phytochrome -induced dormancy in same crop. Seed priming is controlled hydration of seeds to a level that allow pre-germinative metabolic activity to continue, but interrupt the emergence of the radicle. Seed priming improves seed performance, ensures uniformity and better establishment, enhances the yield in diverse environments, greater tolerance to environmental stress and helps to overcome dormancy. Change in seed water content, cell cycle regulation, modification of seed ultrastructure, management of oxidative stress and reserve mobilization are the major physiological and a biochemical change takes places during seed priming.

During subsequent germination, primed seeds exhibit a faster and more synchronized germination and young seedling are often more vigorous and resistant to abiotic stresses than the seedlings obtained from unprimed seeds. Priming allows some of the metabolic processes necessary for germination to occur without germination. In priming, seeds are soaked in different solutions with high osmotic potential. This prevents the seeds from absorbing in enough water for radicle protrusion thus, suspending the seeds in the lag phase. Seed priming has been commonly used to reduce the time between seed sowing and seedling emergence and to synchronize emergence. Several physiological and biochemical changes by priming in French bean were reported by Sarika et al., (2013) ${ }^{[4]}$. In seed priming, the osmotic pressure and the period for which the seeds are maintained in contact with the membrane are sufficient to allow pre-germinative metabolic processes to take place within the seeds up to a level limited to that immediately preceding radicle emergence. Since germination and seedling establishment are critical steps in plant life, and the successful establishment of plant, not only depend on rapid 
and uniform germination of seed but depend on the ability of rapid germination of the seed under environmental conditions. Besides French bean Bassi et al., (2011) ${ }^{[1]}$ reported in soybean that priming with GA3 @ 50 ppm for 2 hour enhanced emergence, germination and speed of germination as compared to non-primed seeds. Yari et al., (2010) ${ }^{[7]}$ reported that seed priming techniques with $\mathrm{KH}_{2} \mathrm{PO}_{4}$ and $\mathrm{KCl}$ showed good potential to enhance germination, emergence, growth and grain yield of wheat influences the germination and early growth of wheat cultivars. For this purpose, seed pre-priming or priming methods are used to increase the qualitative and quantitative performances of seedlings.

\section{Materials and Method}

The field experiment entitled "Effect of different seed priming treatments on vegetative and yield attributing characters of French bean (Phaseolus vulgaris L.)" was carried out during Rabi season of the year 2018-19 in the Vegetable Demonstration plot of the Department of Vegetable Science, College of Agriculture, Orissa University of Agriculture and Technology, Bhubaneswar, Odisha.

\section{Preparation of treated seeds}

In case of hydro priming the seeds were immersed inside water for about $5 \mathrm{hrs}$. Then the seeds were taken out as well as air dried followed by sowing in prepared field. In case of $\mathrm{GA}_{3} 50$ ppm, $\mathrm{KCl}(2 \%)$, Sodium molybdate (500 ppm), Vitavax (2g /1lit), Pseudomonas fluroscens (10\%), Trichoderma viride (10\%), ( $\mathrm{GA}_{3} 50 \mathrm{ppm}+$ Trichoderma viride 10\%), (Sodium molybdate $500 \mathrm{ppm}+$ Pseudomonas fluroscens $10 \%$ ) solution was prepared and the same procedure was followed for treatment of the seeds.

\section{Sowing and sampling technique}

Seeds were hand dibbled to a depth of $3-4 \mathrm{~cm}$, at a row spacing of $50 \mathrm{~cm}$ and plant to plant spacing $30 \mathrm{~cm}$, in small furrows opened with the help of trench hoe and well covered with soil. From each treatment ten number plants were selected randomly were tagged for recording various biometric observations. The mean of the ten plants was considered for further analysis. The observations on various growth parameters were recorded from the selected plants. The border plants were excluded while selecting the sample plants.

\section{Phenological Parameters}

The number of days required for the plants in each plot to show initiation of flowering were observed and recorded. The number of days taken from sowing to days when 50 percent of the plants come to flowering in the field was calculated and the mean average was represented in days

\section{Growth parameters}

Ten trifoliate leaves from each treatment were collected from sample plants and leaf area was measured by leaf area meter and the average was calculated in square centimetre. Ten numbers of compound leaves of French bean were selected from the tagged plants and the total leaf weight was taken and the average leaf weight was expressed in gram. Stem girth of 10 tagged plant from each treatment was measured by thread followed by scale then stem girth per plant was computed from the observed data. During the experiment the numbers of leaves produced by the sample plants at final harvest were counted and average data was used for statistical calculation. The number of branches of the ten selected tagged plants was counted at the final harvest of the crop and the mean was recorded as number of primary branches per plant. The plant height of ten plants was measured from the base of the plant to the base of the fully opened youngest trifoliate leaf and the average was expressed in $\mathrm{cm}$.

\section{Results and Discussion \\ Influence of priming on flowering}

Days to first flowering as influenced by various treatments is presented in Table- 1. It was found that maximum number of days to first flowering was recorded in control that is $\mathrm{T}_{10}$ (44.50) followed by $43.70 \mathrm{~T}_{4}$ and $\mathrm{T}_{8}$ 43.20. In treatment $\mathrm{T}_{3}$ ( $\mathrm{KCl} 2 \%$ ) only 40.60 days was required for first flowering. There is no significant difference among the treatments though the control plot recorded more days to first flowering. Days to first flowering and $50 \%$ flowering was found to be much influenced by various methods of priming. The hydro priming approach resulted the least 40.3 days to first flowering closely followed by 40.6 days in $\mathrm{KCl} 2 \%$ and P. fluroscens (10\%). However, the treatments did not produce any significant differences in days required for first flowering. The present findings are in conformity with earlier reports of Maiti et al (2013) ${ }^{[3]}$ and Singh et al (2014) ${ }^{[5]}$.

The number of days taken to $50 \%$ flowering is presented in Table-1. It was observed that in $\mathrm{T}_{4} 48.70$ days were taken for days to $50 \%$ flowering, followed by $\mathrm{T}_{10}(48.50)$ and $\mathrm{T}_{8}(47.80)$. It was noticed that $\mathrm{T}_{6}$ took lowest number of days (45.50) for $50 \%$ flowering followed by $\mathrm{T}_{2}$ in which 45.60 days was required for flowering. It was observed that none of the treatment produced any significant effect for days to $50 \%$ flowering. There is also no significant changes in days to $50 \%$ flowering. However, the treatments $\mathrm{T}_{10}$ (Control), $\mathrm{T}_{2}\left(\mathrm{GA}_{3} 50\right.$ $\mathrm{ppm})$ and $\mathrm{T}_{3}(\mathrm{KCl} 2 \%)$ recorded comparatively less $45.5,45.6$ and 46.2 days to fifty percent flowering respectively. Singh et al. (2014) ${ }^{[5]}$ also recorded earlier plant growth due to osmo, hydro and halo priming in cowpea seeds.

The average leaf area of compound leaves is presented in Table 1. Highest leaf area of $148.3 \mathrm{~cm}^{2}$ was recorded in $T_{3}$ followed by $140.4 \mathrm{~cm}^{2}$ in $\mathrm{T}_{8}, 138.40 \mathrm{~cm}^{2}$ in $\mathrm{T}_{2}$ and $132.6 \mathrm{~cm}^{2}$ in $\mathrm{T}_{5}$. The lowest average leaf area was found with $\mathrm{T}_{10}\left(105.8 \mathrm{~cm}^{2}\right)$. It was observed that all of the treatments produced significant difference so far as average leaf area was concerned as compared to control. The priming with $\mathrm{KCl}(2 \%)$ recorded the highest average leaf area $\left(148.3 \mathrm{~cm}^{2}\right)$ closely followed by $\mathrm{T}_{8}$ $\left(\mathrm{GA}_{3} 50 \mathrm{ppm}+\right.$ T.viridae $\left.10 \%\right) 140.4, \mathrm{~T}_{2}\left(\mathrm{GA}_{3} 50 \mathrm{ppm}\right) 138.4, \mathrm{~T}_{5}$ (Vitavax $2 \mathrm{~g} / \mathrm{kg}$ )132.6, $\mathrm{T}_{7}$ (T. viridae $\left.10 \%\right) 132.5$ and $\mathrm{T}_{6}$ (P.fluorescens $10 \%) 131.7$ which are statistically at par and significantly different from $\mathrm{T}_{1}$ (Hydro priming) 128.9, $\mathrm{T}_{4}$ (Sodium Molybdate500 ppm)128.4, $\mathrm{T}_{9}$ (Sodium Molybdate 500 ppm $+P$. fluorescens (10\%) 125.6 and control (105.8) However the leaf size in all the treatments were found to have more leaf area as compared to control.

The observation on fresh weight of leaf is presented in Table 1. The average fresh weight of leaf was highest in $\mathrm{T}_{8}(3.24 \mathrm{~g})$ followed by $\mathrm{T}_{2}(3.14 \mathrm{~g}), \mathrm{T}_{3}(3.10 \mathrm{~g})$ and $\mathrm{T}_{9}(2.91 \mathrm{~g})$ and $\mathrm{T}_{6}(2.85)$ which are statistically at par. The lowest average leaf weight $2.44 \mathrm{~g}$ was recorded in $\mathrm{T}_{1}$. Among the treatments hydro priming recorded the least fresh weight of leaf $(2.44 \mathrm{~g})$ in $\mathrm{T}_{1}$. Results revealed the highest fresh leaf weight was in $\mathrm{T}_{8}(3.24 \mathrm{~g})$ followed by $\mathrm{T}_{2}(3.14 \mathrm{~g}), \mathrm{T}_{3}(3.10 \mathrm{~g}), \mathrm{T}_{9}(2.91 \mathrm{~g})$ and $\mathrm{T}_{6}(2.85)$ and they are at par. There is not any significant variation among the treatments showing that different priming agents as well as their combination did not have any impact on fresh weight of leaf.

The observation on stem girth is presented in Table 1. It was observed that due to different priming treatment the highest 
stem girth of $2.8 \mathrm{~cm}$ was recorded in $\mathrm{T}_{3}$. However $\mathrm{T}_{8}$ recorded stem girth of $2.7 \mathrm{~cm}$ closely followed by $2.6 \mathrm{~cm}$ in $T_{5}$. The lowest stem girth of $2.1 \mathrm{~cm}$ was recorded with control. Highest stem girth of $2.8 \mathrm{~cm}$ was recorded in $\mathrm{T}_{3}(2.8 \mathrm{~cm})$ closely followed by $\mathrm{T}_{8}(2.7 \mathrm{~cm})$. However halo priming, hormo priming, combination of hormo and bio priming as well as chemical seed treatment recorded higher stem girth than control and other treatments.

Table 1: Days to first flowering, 50\% flowering, leaf characters and stem girth of French bean crop as influenced by priming

\begin{tabular}{|c|c|c|c|c|c|c|}
\hline & Treatment & $\begin{array}{c}\text { Days to first } \\
\text { flowering }\end{array}$ & $\begin{array}{c}\text { Days to } 50 \% \\
\text { flowering }\end{array}$ & \begin{tabular}{|c|}
$\begin{array}{c}\text { Average leaf } \\
\text { area }(\mathrm{cm})^{2}\end{array}$ \\
\end{tabular} & $\begin{array}{c}\text { Fresh weight } \\
\text { of leaf }(\mathrm{g})\end{array}$ & $\begin{array}{l}\text { Stem girth } \\
\text { in }(\mathbf{c m})\end{array}$ \\
\hline T1 & Hydro priming & 40.30 & 47.30 & 128.9 & 2.44 & 2.4 \\
\hline $\mathrm{T} 2$ & $\mathrm{GA}_{3}(50 \mathrm{ppm})$ & 42.00 & 45.60 & 138.4 & 3.14 & 2.5 \\
\hline T3 & $\mathrm{KCl}(2 \%)$ & 40.60 & 46.20 & 148.3 & 3.10 & 2.8 \\
\hline T4 & Sodium Molybdate500 ppm & 43.70 & 48.70 & 128.4 & 2.68 & 2.5 \\
\hline T5 & $\operatorname{Vitavax}(2 \mathrm{~g} / \mathrm{kg})$ & 42.50 & 46.50 & 132.6 & 2.62 & 2.6 \\
\hline T6 & $P$ fluorescens $(10 \%)$ & 40.80 & 45.50 & 131.7 & 2.85 & 2.5 \\
\hline $\mathrm{T} 7$ & T. viride $(10 \%)$ & 41.20 & 46.50 & 132.5 & 2.56 & 2.4 \\
\hline T8 & $\mathrm{GA}_{3}(50 \mathrm{ppm})+T$ viride $(10 \%)$ & 43.20 & 47.80 & 140.4 & 3.24 & 2.7 \\
\hline T9 & Sodium Molybdate $500 \mathrm{ppm}+P$ fluorescens $(10 \%)$ & 41.40 & 46.40 & 125.6 & 2.91 & 2.4 \\
\hline $\mathrm{T} 10$ & Control & 44.50 & 48.50 & 105.8 & 2.70 & 2.1 \\
\hline & $\mathrm{SE}(\mathrm{m}) \pm$ & 2.00 & 2.17 & & 6.09 & 0.14 \\
\hline & CD 5\% & 6.08 & 6.59 & & 18.46 & 0.41 \\
\hline & $\mathrm{CV} \%$ & 8.26 & 8.02 & & 8.04 & 8.32 \\
\hline
\end{tabular}

\section{Effect on Number of leaves, primary branch and plant height}

The number of leaves per plant was recorded at harvest and is presented in Table 2. The highest number of leaves (20.5) were obtained in $\mathrm{T}_{7}$ followed by $\mathrm{T}_{3}(19.2)$ and $\mathrm{T}_{8}(18.6)$ and $\mathrm{T}_{2}(18.4)$ which are statistically at par. However, the number of leaves per plant was lowest in $\mathrm{T}_{10}(15.2)$ followed by $\mathrm{T}_{9}(15.6) . \mathrm{T}_{7}, \mathrm{~T}_{3}$, $\mathrm{T}_{8} \& \mathrm{~T}_{2}$ produced significantly higher leaves than $\mathrm{T}_{10}$ (control). The no. of leaves were found to be highest (20.5) in $\mathrm{T}_{7}(T$. viridae $10 \%)$ closely followed by $\mathrm{T}_{3}(\mathrm{KCl} 2 \%)$ that is 19.2 . Though there is not any definite pattern for increase or decrease of no. of leaves by priming approach either sole or in combination but the unprimed control recorded the lowest no. of leaves (15.2) during growth period. This finding is in close conformity with the results of singh et al. (2016) who experimented and found priming with bio control agents increased the number of leaves and other plant growth characters.

The number of primary branches per plant as recorded at harvest is presented in Table 2. It was found that there was significant differences in number of branches per plant and it was highest with $\mathrm{T}_{3}$ (4.52) followed by $\mathrm{T}_{2}$ (4.14), $\mathrm{T}_{8}(4.32), \mathrm{T}_{5}$ (4.01) and $T_{7}$ (3.98) and they are statistically at par. The minimum number of branches was recorded in $\mathrm{T}_{10}(2.87)$ followed by $\mathrm{T}_{4}$ (2.95), $\mathrm{T}_{1}$ (3.27) and $\mathrm{T}_{6}$ (3.29). The number of branches were found to be highest $(4.52)$ in $(\mathrm{KCl} 2 \%)$ treatment followed by $\mathrm{T}_{8}$ (4.32), $\mathrm{T}_{2}$ (4.14), $\mathrm{T}_{5}$ (4.01) and $\mathrm{T}_{7}$ (3.98). The least no. of branches were recorded in control (2.87). It may be concluded that when number of branches increased, there is increase in number of leaves. However there is significant difference among the treatments in producing number of branches per plant and number of leaves per plant indicating that these two characters respond well to priming approach and different environmental, edaphic, climatic and nutritional factors which had profound influence on those two characters during the period of experimentation. Soliman et al. (2016) also reported this type of findings in faba bean.

The data on plant height is presented in Table 2 revealed that all the priming treatments were significantly different from control (39.83). Highest plant height of $45.91 \mathrm{~cm}$ was observed in $\mathrm{T}_{3}(\mathrm{KCl} 2 \%)$ which was followed at par with other treatments but significantly higher than the unprimed control. Priming treatments with $\mathrm{KCl} 2 \%$ recorded the highest plant height $(45.91 \mathrm{~cm})$ which was at par with other treatments but significantly higher than the unprimed control $(39.83 \mathrm{~cm})$. This finding is in close agreement with the result of Maiti et al. (2013) ${ }^{[3]}$ \& Ghobadi et al. (2014) ${ }^{[2]}$ who recorded higher plant height in halo priming when investigated in different vegetable crops.

Table 2: Number of leaves and number of branches at harvest of French bean crop as influenced by different treatments

\begin{tabular}{|c|c|c|c|c|}
\hline \multicolumn{2}{|r|}{ Treatments } & \multirow{2}{*}{$\begin{array}{c}\begin{array}{c}\text { Number of leaves } \\
\text { at harvest }\end{array} \\
16.2 \\
\end{array}$} & \multirow{2}{*}{\begin{tabular}{|c|}
$\begin{array}{c}\text { Primary branches } \\
\text { at harvest }\end{array}$ \\
40.30 \\
\end{tabular}} & \multirow{2}{*}{$\begin{array}{c}\begin{array}{c}\text { Plant height at } \\
\text { harvest }(\mathbf{c m})\end{array} \\
3.27\end{array}$} \\
\hline $\mathrm{T} 1$ & Hydropriming & & & \\
\hline $\mathrm{T} 2$ & $\mathrm{GA}_{3}(50 \mathrm{ppm})$ & 18.4 & 42.43 & 4.14 \\
\hline T3 & $\mathrm{KCl}(2 \%)$ & 19.2 & 45.91 & 4.52 \\
\hline $\mathrm{T} 4$ & Sodium Molybdate $500 \mathrm{ppm}$ & 16.2 & 40.97 & 2.95 \\
\hline T5 & Vitavax $(2 \mathrm{~g} / \mathrm{kg})$ & 17.5 & 41.20 & 4.01 \\
\hline T6 & P. fluorescens $(10 \%)$ & 15.8 & 40.20 & 3.29 \\
\hline $\mathrm{T} 7$ & T. viridae $(10 \%)$ & 20.5 & 41.72 & 3.98 \\
\hline T8 & $\mathrm{GA}(50 \mathrm{ppm})+T$. viridae $(10 \%)$ & 18.6 & 43.23 & 4.32 \\
\hline T9 & Sodium Molybdate $500 \mathrm{ppm}+P$. fluorescens $(10 \%)$ & 15.6 & 41.40 & 3.31 \\
\hline $\mathrm{T} 10$ & Control & 15.2 & 39.83 & 2.87 \\
\hline \multicolumn{2}{|c|}{ SE $(\mathrm{m}) \pm$} & 0.81 & 0.28 & 1.93 \\
\hline \multicolumn{2}{|c|}{ CD5\% } & 2.47 & 0.86 & 5.84 \\
\hline \multicolumn{2}{|r|}{$\mathrm{CV} \%$} & 8.14 & 13.33 & 8.00 \\
\hline
\end{tabular}




\section{Conclusion}

Days to first flowering mean varied from 40.30 in $T_{1}$ to 44.5 in $\mathrm{T}_{10}$. There was no significant difference in days to first flowering among the treatments. Days to $50 \%$ flowering varied from 45.5 in $\mathrm{T}_{6}$ to 48.7 in $\mathrm{T}_{4}$. There was also no significant difference for days to $50 \%$ flowering among the treatments. The average leaf area of the trifoliate compound leaves were taken which was highest in $\mathrm{T}_{3}(148.30)$ followed by $140.40 \mathrm{~cm}^{2}$ in $\mathrm{T}_{8}$ and was lowest $105.8 \mathrm{~cm}^{2}$ in $\mathrm{T}_{10}$. The unprimed control treatment recorded significantly the least average leaf size. Fresh weight of leaves as found during the experiment varied from 2.44 to 3.24 among all the treatments and there was not much variation for this character. However the unprimed plot recorded significantly less weight of fresh leaf compared to $\mathrm{T}_{8}$ $\& \mathrm{~T}_{3}$. The highest stem girth $(2.8 \mathrm{~cm})$ was recorded in $\mathrm{KCl}(2 \%)$ primed seeds closely followed by $\mathrm{GA}_{3}(50 \mathrm{PPM})+T$. viride $(10 \%)(2.7 \mathrm{~cm})$ and vitavax treatment @ $2 \mathrm{~g} / \mathrm{kg}(2.6 \mathrm{~cm})$. The number of leaves per plant ranged from 15.2 to 20.5 and $\mathrm{T}_{9}$ (15.60), $\mathrm{T}_{6}(15.8), \mathrm{T}_{1} \& \mathrm{~T}_{4}$ (16.2), $\mathrm{T}_{5}$ (17.5) were found to be significantly differed from other treatments for this character. The number of primary branches per plant was maximum in $\mathrm{T}_{3}$ (4.52) and minimum in $\mathrm{T}_{10}$ (2.87) and this character differed significantly among the treatments. The treatments $\mathrm{T}_{3}(4.52)$, $\mathrm{T}_{8}$ (4.32), $\mathrm{T}_{6}(4.14), \mathrm{T}_{5}(4.01)$ produced more branches and they are at par.

\section{References}

1. Bassi G, Sharma S, Gill BS. Pre-sowing seed treatment and quality in-vigouration in soybean (Glycine $\max (\mathrm{L})$ Merrill). Seed Res. 2011; 31:81-84.

2. Ghobadi M, Abnavi MS, Mohammadi R. Effect of Hormonal Priming $\left(\mathrm{GA}_{3}\right)$ and Osmo priming on Behavior of Seed Germination in Wheat (Triticum aestivum L.). Journal of Agricultural Science. 2014; 4(9):212-215.

3. Maiti R, Rajkumar D, Jagan M, Parmanik K, Vidyasagar P. Effect of Seed Priming on Seedling Vigour and Yield of Tomato and Chilli. International Journal of Bio-resource and Stress Management. 2013; 4(2):119-125.

4. Sarika G, Basavaraju GV, Bhanuprakash K, Chaanakeshava V, Paramesh R, Radha BN. Investigation on seed viability and vigour of aged seed by priming in French bean. Veg Sci. 2013; 40:169-173.

5. Singh A, Dahiru R, Musa M, Haliru BS. Effects of osmopriming duration on germination, emergence and early growth of cowpea (Vigna unguiculata (L.) Walp.) In the Sudan Savannah. Nigeria. Int J Agron. 2014; 4(3):64-68.

6. Soliman MH, Al-Juhani RS, Hushas MA, Al-Juhani FM. Effect of seed priming with Salicylic acid on seed germination and seedling growth of broad bean (Vicia faba L.). International Journal of Agricultural Technology. 2016; 12(6):1125-1138.

7. Yari L, Aghaalikani M, Khazaei F. Effect of seed priming duration and temperature on seed germination behaviour of bread wheat (Triticum aestivum L.). ARPN J Agric Biol Sci. 2010; 5:1-7. 